\title{
Evaluation of the Protective Effect of Ethanolic Extract of Plantago major Plant Against CCl4 Induced Genotoxicity and Biochemical Disturbance in Rat
}

\author{
Z.A. Nofal *, A.F. El-Maghraby", M. R. $\operatorname{Gad}^{* *}$, A. A. \\ Farghaly ${ }^{* * *}$ and E.M.A. Attia \\ *Biochemstry Department, Faculty of Agriculture, Al-Azhar \\ University, ${ }^{* *}$ Food Technology Research Institute, Agricultural \\ Research Centre, ${ }^{* * *}$ Genetics and Cytology Department, \\ National Research Centre and ${ }^{* * * *}$ Orimental and Medicine \\ Plants Department, Horticulture Research Institute, \\ Agricultural Research Centre, Cairo, Egypt.
}

\begin{abstract}
7 HIS STUDY was carried out through 2010-2014, seasons on fresh herbs of Plantago major plant, which was collected from a private nurseries of El Qanater el Khayreyya, Al- Qaluobia Governorate, Egypt. The aim of this study was to investigate the protective potential of ethanolic crud extract of Plantago major against oxidative stress induced by carbon tetrachloride $\left(\mathrm{CCl}_{4}\right)$ in different tissues in rats. Our results observed that $\mathrm{CCl} 4$ exhibited a significant increase in the levels of serum glucose and lipid profile i.e. total cholesterol, triglyceride and low density lipoprotein cholesterol (LDL) with a significant decrease in the level of high density lipoprotein cholesterol (HDL). Also, CCl4 increase liver function including serum aminotransferases (AST and ALT), alkaline phosphatase (ALPh), total protein, albumin (ALB) and total bilirubin activities and kidney function including the levels of serum urea, uric acid and creatinine amounts. Treatment with ethanolic $P$. major extract at $100 \mathrm{mg} / \mathrm{kg}$ b.wt before, with and after treatment with $\mathrm{CCl} 4$ significantly prevented all of these typically observed changes . Also, $P$. major extract statistically significant $(P<0.01)$ inhibit DNA damage induced by $\mathrm{CCl} 4$ in bone marrow and sperms of rats. Our findings indicate that $P$. major has a significant protective effect against $\mathrm{CCl} 4$ induced genotoxicity and biochemical changes in rat, which may be due to its antioxidant properties.
\end{abstract}

Keywords: Plantago major herb, Carbon tetrachloride, Chromosomal abnormality, Biochemical analysis.

Carbon tetrachloride $\left(\mathrm{CCl}_{4}\right)$, a clear, colorless, volatile, heavy and nonflammable industrial liquid, widely used to induced free radical toxicity in various tissues of experimental animals such as liver, kidneys, heart, lung, testis, brain and blood (Khan et al., 2010). $\mathrm{CCl}_{4}$ is converted through hepatic microsomal cytochrome

Corresponding author: Farghaly, A.A

E-mail: ayman.a.farghaly@gmail.com 
P450 into trichloromethyl-free radical $\left(\mathrm{CCl}_{3}\right.$ or $\left.\mathrm{CCl}_{3} \mathrm{OO}\right)$ (Preethi and Kuttan, 2009) which in turn, initiate lipid peroxidation process (Adewole et al., 2012). The most widely accepted mechanism of $\mathrm{CCl}_{4}$ induced hepatotoxicity is the formation of free radicals which is a rate limiting process in tissue peroxidative damage (Sahreen et al., 2011 and Khan et al., 2011). This free radical and related reactive species may cause oxidative stress, which produces major interconnected changes of cellular metabolism, increases the serum marker enzymes, DNA fragmentation, and destruction of the cells by lipid peroxidation (Bhadauria et al., 2008). The accumulation of lipid peroxides introduces hydrophophilic moieties and alters membrane permeability and cell function which causes the loss of hepatic integrity and depressed hepatic function resulting in hepatotoxicity and congestive hepatic failure (Khan et al., 2012). To protect the body from such deleterious effects of free radicals, several endogenous enzymatic and non enzymatic systems are provided, but when the formation of free radicals is excessive, additional protective mechanisms of dietary antioxidants may be of a great importance (Tirkey et al., 2005). Maintaining the balance between reactive oxygen species and natural antioxidants is therefore crucial, and could serve as a major mechanism in preventing damage by oxidative stress induced by toxic agents. Cooperative defense systems that protect the body from free radical damage include the antioxidant nutrients and enzymes (Sreelatha et al., 2009). Antioxidant and radical scavengers have been used to study the mechanism of $\mathrm{CCl}_{4}$ toxicity as well as to protect tissue cells from $\mathrm{CCl}_{4}$ induced damage by breaking the chain of lipid peroxidation (Weber et al., 2003). Numerous studies have shown that horticultural crops and fruits are sources of diverse antioxidant properties, which can protect body against $\mathrm{CCl}_{4}$, induced oxidative stress (Ogeturk et al., 2005).

With respect to cytotoxic, genotoxic or mutagenic activity of chlorinated aliphatic hydrocarbons the data showed that the DNA reactivity such of compounds increased with increasing degree of halogenisation (Tafazoli and Kirsch-Volders, 1996). The carcinogenic potential of carbon tetrachloride has been early shown by (Weisburger, 1977) in mice in which liver and adrenal tumors were induced, and in rats in which disseminated neoplastic nodules were observed after oral exposure. The positive clastogenic effect has been demonstrated by in vitro conditions in metabolic competent.MCL-5 and h2E1 human cell lines (Doherty et al., 1996) and in workers occupationally exposed to mixture of chlorinated solvents or carbon tetrachloride in comparison to the group that was not exposed (Da Silva et al., 1997). Dianovsk and Ivikova (2001) showed a significant increase of sister chromatid exchange (SCE) in sheep peripheral lymphocytes after CCl4 treatment. Tafazoli et al. (1998) pointed out in their report that mutagenicity of $\mathrm{CCl} 4$ occurred in absence of significant cytotoxicity.

Medicinal and aromatic plants use by $80 \%$ of global population for their medicinal therapeutic effects as reported by WHO (2008). Many of these plants

Egypt. J. Vet. Sci. Vol. 47, No. 1 (2016) 
synthesize substances that are useful to the maintenance of health in humans and other animals. These include aromatic substances, most of which are phenols or their oxygen-substituted derivatives such as tannins. Others contain alkaloids, glycosides, saponins, and many secondary metabolites (Naguib, 2011).

Among many popular medicinal plants, plantago has accessed a scientific value, as it has been taken place in many historical uses as a wound healing remedy for centuries (Dokuparthi and Manikanta, 2015). P. major is commonly called as "blonde psyllium" in English and "Isabgol" in Hindi and Urdu, $P$. major is the member of the family of Plantaginaceae, which is a vastly diverse genus, including around 256 species (Dhar et al., 2005).

P. major contained active components such as, mucilages, flavonoids, phenolic acids, hydroxycoumarins, tannins and antioxidant activities (Blumenthal et al., 2000). Phytochemical studies have also shown that the genus Plantago contains a great amount of phenolic compounds (flavonoids and tannins). In particular, phenolic compounds seem to play a potential role in the control of bacterial growth and could prevent tooth decay, decreasing growth, and virulence of pathogenic oral flora (Smullen et al., 2007). A recent study has reported that $P$. major methanol/water extracts are rich in phenolic acids, with the benzoic acid derivatives hydroxybenzoate and 3,4,5-trihydroxybenzoate (gallic acid) being the most highly represented (Beara et al., 2012).

Furthermore, experimental studies have proven that this plant has antiulcerogenic activities (Atta et al., 2005), anti-inflammatory activities (Beara et al., 2010), antigiardiasic activity (Ponce-Macotela et al., 1994), antimalarial activity (Weenen et al., 1990), anticancer activities (Mohamed et al., 2011), immunomodulatory activity (Chiang et al., 2003), wound healing activities (Zubair et al., 2012), antioxidant activities (Stanisavljevic et al., 2008 and Beara et al., 2009), antimicrobial activities (Stanisavljevic et al., 2008), antihypoglycaemic activity (Díez-Láiz et al., 2015), decreases in the levels of serum BUN urea and serum creatinine (Hong et al., 2011), hepatoprotective activity (Hussan et al., 2015), hyperlipidemic activity (Hu et al., 2014) and haemopoietic and cytotoxic activity (Velasco-Lezama et al., 2006).

The aim of the present study was to investigate protective effect of $P$. major ethanolic extract against $\mathrm{CCl} 4$-induced hepatotoxicity and genotoxicity in rats.

\section{Material and Methods}

\section{Plant materials}

Fresh herbs of $P$. major was collected form a private nurseries of El-Qanater El-Khayreyya, Al-Qaluobia Governorate, Egypt. Plant material was authentified by the Flora Department of Horticulture Research Institute, Agricultural Research Center, Giza governorate, Egypt (August 2010). 
Chemical composition

Moisture, ash, crude protein, crude fiber and vitamin $C$.

Moisture, ash, crude protein, crude fiber and vitamin $\mathrm{C}$ were determined as recommended by A.O.A.C. (2005).

\section{Minerals determination.}

Nitrogen was determined by the modified microkjeldahl method as described by Pregl (1945). Phosphorus content was colorimetrically determined according to the method of Jackson (1958). Potassium was determined using Flame Photometer apparatus according to Jackson (1967).

Determination of total free amino acids.

Total free amino acids were determined by Jayaraman (1985).

Total sugars (Reducing - Non-reducing).

Total sugars were determined by Miller (1959).

Total carbohydrates.

Total carbohydrates were determined by Smith et al. (1956).

Determination of chlorophyll $a \& b$ and carotoinds.

Chlorophyll-A, chlorophyll-B and carotenoids were extracted from leaves according to the methods of Sweeney and Martin (1958).

Determination of total indoles compounds.

Extraction of indolic compounds was conducted according to the method described by Daniel and George (1972).

Fatty acid.

Fatty acid was determined as recommended by A.O.A.C. (2005).

Volatile oil (Essential oil).

Essential oils was determined according to the method of Guenther (1960).

Identification and determination of fatty acids.

Fatty acid profiles were determined according to the method of (Aura et al., 1995) utilizing a gas chromatograph.

Preparation of ethanolic plant extract (Soxhlet extraction)

Plant materials were dried at oven temperature on $50^{\circ} \mathrm{C}$, and grounded in a mortar. Two hundred and fifty grams of each plant powder was extracted in 1000 $\mathrm{ml}$ of solvent in dark colored bottles for the extraction process by maceration (36 h). Resulted suspension was filtered through white Whatman filter paper. Pellet was re-extracted using solvent repeatedly for 2 more times. But each time the amount of the solvent was decreased. Three or more times filtrates were collected to remove the used solvent using rotary evaporator at $40^{\circ} \mathrm{C}$. Crude extract was kept at $-8^{\circ} \mathrm{C}$ until further experiments.

Egypt. J. Vet. Sci. Vol. 47, No. 1 (2016) 


\section{Extract analysis for active ingredient}

Total Phenols

Extraction of phenolic compounds was conducted according to the method described by Daniel and George (1972).

Total flavonoids

Total flavonoids were estimated using method of Sakanaka et al. (2005).

Identification of phenols by HPLC.

Phenols were fractionated using HPLC (HP 1100) according to Merfort et al. (1997).

Total antioxidant activity

The antioxidant activity of the extracts was studied through the evaluation of the free radical scavenging effect on the 2,2 diphenyle 1-1picrylhydrazl (DPPH). The determination were assessed by Brand-Williams et al. (1995).

\section{Total alkaloids}

Total alkaloids content was determined by Shamsa, et al. (2008).

Hydrolysable tannins content.

Hydrolysable tannins content were determined by the method of Çam and Hişil (2010).

\section{Saponine content}

Saponine content was determined as described by and Uematsu et al. (2000).

Detection for Terpenoid

A reddish brown precipitate coloration at the interface formed, indicated the presence of terpenoids according to Ganatra et al. (2012).

\section{Experimental animals}

Laboratory-bred strain male rat weighting of 200-250 g obtained from the animal house of Research Institute of Ophthalmology, Giza, Egypt. Animals were housed in groups (5 animals/group) and maintained under standard condition of temperature, humidity and light. The animals were given standard food and water ad libitum.

\section{Experimental Design}

For hepatoprotective evaluation of ethanolic extract of $P$. major against liver damage induced by $\mathrm{CCl} 4$ for 7 days.

The CCl4 model described by Shenoy et al. (2001) was used for scheduling the dose regimen. Intraperitoneal injection of $0.8 \mathrm{ml} / \mathrm{kg} \mathrm{CCl} 4$ diluted in distilled water (3: 10 dilution) was employed for inducing acute liver toxicity. 
Rats were divided into groups (5 animals/group) as follow

- Control group (non treated, negative control).

- $\quad \mathrm{CCl} 4$ model group $0.8 \mathrm{ml} / \mathrm{kg} /$ day for 7 days (positive control).

- Ethanolic extract of $P$. major group with the dose $100 \mathrm{mg} / \mathrm{kg}$ body weight for 7 days.

- $\quad$ Ethanolic extract of $P$. major group with the dose $100 \mathrm{mg} / \mathrm{kg}$ body weight $4 \mathrm{~h}$ before $\mathrm{CCl} 4$ treatment for 7 days.

- Ethanolic extract of $P$. major group with the dose $100 \mathrm{mg} / \mathrm{kg}$ body weight simultaneously with $\mathrm{CCl} 4$ treatment for 7 days.

- $\quad$ Ethanolic extract of $P$. major group with the dose $100 \mathrm{mg} / \mathrm{kg}$ body weight $4 \mathrm{~h}$ after $\mathrm{CCl} 4$ treatment for 7 days.

Blood and liver samples were collected $24 \mathrm{~h}$ after the last treatment. At the end of experiment, blood was collected in tubes from retro-orbital vein in separated tubes. The tube was centrifuged at $3000 \mathrm{rpm}$ for $20 \mathrm{~min}$, for serum preparation.

Biochemical assay

Serum glucose

Glucose presented in the sample was determined according to the procedure of Trinder (1969).

\section{Lipid profile}

- Determination of total cholesterol

- Total cholesterol was calorimetrically determined at $546 \mathrm{~nm}$ according to the enzymatic method described by Allain et al. (1974).

- Determination of triglyceride

- Serum triglyceride was determined according to the method described by Fossati and Principe (1982).

- Determination of high density lipoprotein cholesterol (HDL)

- Serum high density lipoprotein cholesterol was determined by the method described by Tietz (1976a).

- Determination of low density lipoprotein cholesterol (LDL)

- $\quad$ Serum LDL-cholesterol was calculated according to Tietz (1976a).

Liver functions

- Determination of serum aspartate transferase activities (AST-GOT)

- Serum aspartate transferase (AST) activities were measured calorimetrically according to the method of Tietz (1976b).

- Determination of serum alanine transferase activities (ALT-GPT)

- Serum alanine transferase (ALT) activities were measured colorimetrically according to the method of Tietz (1976b).

- Determination of alkaline phosphatase (AL Ph)

- Alkaline phosphatases (AL Ph) in serum were determined according to the method of Young et al. (1972).

- Determination of serum total protein

- Serum total protein was measured according to the method described by Vassault et al. (1986).

Egypt. J. Vet. Sci. Vol. 47, No. 1 (2016) 
- $\quad$ Determination of Albumin (ALB)

- Albumin in serum was determined according to the method of Young et al. (1975).

- Determination of total bilirubin

- Bilirubin in serum was determined according to the method of Walters and Gerarde (1970).

- Kidney function

- Determination of serum urea

- Serum urea was determined according to Tietz (1990)

- Determination of serum creatinine

- Creatinine in serum was determined according to the method of Tietz (1986).

- Determination of uric acid

- Uric acid in serum was determined according to the method of Vassault et al. (1986).

Cytogenetic studies

Doses

For cytogenetic analysis, animals treated with the same doses and time of treatment as in hepatoprotective study. For somatic cells animals treated for 7 days and samples collected $24 \mathrm{~h}$ after the last treatment. For somatic cells preparation, animals from the different groups were injected i.p. with colchicine, 2-3h before sacrifice. In germ cells animals treated for 5days. Samples taken after 35 days from the first treatment (cell cycle of sperm preparation from spermatocyt cells takes about 35 days).

Chromosome aberrations in somatic cells

Chromosome preparations from bone - marrow (somatic cells) carried out according to the method of Yosida and Amano (1965). 100 well spread metaphases were analyzed per rat. Metaphases with gaps, chromosome or chromatid breakage, fragments, deletions, as well as numerical aberrations (polyploidy) were recorded.

Sperm-shape abnormalities

Sperm were prepared according to the recommended method of Wyrobek and Bruce (1978).1000 sperm were analyzed per rat. Sperms with straight, banana shape, amorphous, without hook, as well as coiled tail were recorded.

Evaluation of the activity of plant extract to reduce abnormalities induced by CCl4 was carried out according to Madrigal-Bujaidar et al. (1998) formula as follows

Inhibitory index $(\mathrm{II})=[1-($ plant extract and $\mathrm{CCl} 4-$ control $) /(\mathrm{CCl} 4-$ control)] X100

\section{Statistical analysis}

The complete randomized blocks design was adopted for the experiment. The statistical analysis of the present data was carried out according to the methods described by Snedecor and Cochran (1980). Averages were compared using the new LSD method at $5 \%$ level. For cytogenetic analysis the significance of the results from the negative control data and between plant extract with $\mathrm{CCl} 4$ comparing to $\mathrm{CCl} 4$ alone was calculated using t-test. 


\section{Results and Discussions}

Chemical composition of $P$. major herbs

As shown in Table 1 , data revealed that chemical composition of $P$. major herbs contain $95.56 \%$ moisture, $13.88 \%$ ash, $0.507 \%$ crude fiber, $8.061 \mathrm{mg} / 100 \mathrm{~g}$ F.W. vitamin c, $1.544 \%$ nitrogen, $0.458 \%$ phosphorus, $2.112 \%$ potassium, $1.173 \%$ total free amino acids, $9.653 \%$ crude protein, $4.038 \%$ reducing sugars, $1.497 \%$ non-reducing sugars, $5.534 \%$ total sugars, $3.499 \%$ total carbohydrates, $0.136 \mathrm{mg} / 100 \mathrm{~g}$ F.W. chlorophyll-a, $0.076 \mathrm{mg} / 100 \mathrm{~g}$ F.W. chlorophyll-b, $0.016 \mathrm{mg} / 100 \mathrm{~g} \mathrm{~F}$.W. carotenoids, $8.277 \mathrm{mg} / 100 \mathrm{~g}$ F.W. total indoles, $2.099 \%$ total fatty acid and $0.13 \%$ essential oil. These results are harmony with those (Shad et al., 2013, El-Sheikh 2014 and Ferrazzano et al., 2015).

TABLE 1. Chemical composition of $P$. major herbs.

\begin{tabular}{|l|l|}
\hline \multicolumn{1}{|c|}{ Moisture (\%) } & $\mathbf{9 5 . 5 6}$ \\
\hline Ash (\%) & 13.88 \\
\hline Crude fiber (\%) & 0.507 \\
\hline Vitamin C (mg/100g F.W.) & 8.061 \\
\hline Nitrogen (\%) & 1.544 \\
\hline Phosphorus (\%) & 0.458 \\
\hline Potassium (\%) & 2.112 \\
\hline Total free amino acids (\%) & 1.173 \\
\hline Crude protein (\%) & 9.653 \\
\hline Reducing sugars (\%) & 4.038 \\
\hline Non-reducing sugars (\%) & 1.497 \\
\hline Total sugars (\%) & 5.534 \\
\hline Total carbohydrates (\%) & 3.499 \\
\hline Chlorophyll-A (mg/g F.W.) & 0.136 \\
\hline Chlorophyll-B (mg/g F.W.) & 0.076 \\
\hline Carotenoids (mg/g F.W.) & 0.016 \\
\hline Total indoles (mg/100g D.W.) & 8.277 \\
\hline Total fatty acid (\%) & 2.099 \\
\hline Essential oil (\%) & 0.13 \\
\hline
\end{tabular}

\section{Identification and determination of fatty acids}

Data in Table 2 showed that the total fatty acids of P. major contain $73.05 \%$ of the total unsaturated fatty acid, while the total saturated fatty acid were Egypt. J. Vet. Sci. Vol. 47, No. 1 (2016) 
$26.95 \%$. Lenoleic acid (C18:2) is the major component of the main unsaturated fatty acid, while the main saturated fatty acid is palmetic acid (C16:0).

The main components of fatty acids of $P$. major herbs was $27.96 \%$ for lenoleic acid (C18:2), followed in a descending order by $23.20 \%$ for linolenic acid (C18:3n3) followed by $15.56 \%$ for oleic acid (C18:1) followed by $15.44 \%$ for palmitic acid (C16:0) followed by $4.43 \%$ for myristoleic acid (C14:1) followed by $4.28 \%$ for lauric acid (C12:0) followed by $3.11 \%$ for myristic acid (C14:0) followed by $2.62 \%$ for stearic acid (C18:0) and less than $1 \%$ for palmitoleic acid (C16:1), margaric acid (C17:0), margaolic acid (C17:1), $\alpha-$ linolenic acid(C18:3n6), arachidic acid (C20:0), gadoleic acid (C20:1) and bahenic (C22:0).

The obtained results are in agreement with those reported by Liu et al. (2002) who detected that the total fatty acid content in $P$. major leaves is $286 \mathrm{mg}$ per $100 \mathrm{~g}$ of fresh plant material, the major fatty acids were linolenic, linoleic, and palmitic acid, but smaller amounts of stearic, oleic, and myristic acid. Also, Javed et al. (2003) found that the $P$. ovata seed contain lipid percentage is rather low $(5.2 \%)$ as compared to other oil bearing seeds. The total lipids were classified into neutral and polar lipids by thin layer chromatography. The neutral lipids identified, were hydrocarbons $(1.3 \%)$ wax esters $(2.1 \%)$, triacylglycerols $(74.2 \%)$, free fatty acids $(2.5 \%)$, 1,3-diacylglycerols (3.6\%), 1,2-diacglycerols (3.9\%), glycolipids (1.2\%), fatty alcohols (2.0\%) sterols (1.3\%), 2monoacylglycerols $(2.4 \%)$ and 1 -monoacylglycerols $(3.0 \%)$. The fatty acid range was $\mathrm{C} 14.0$ to $\mathrm{C} 18.3$. All the lipids classes showed higher percentages of unsaturated fatty acids in which linoleic acid $(\mathrm{C} 18.2)$ is predominant one (45.9$61.9 \%)$. The other fatty acids were myristic (C 14.0) palmitic (C 16.0) stearic (C 18.0) Oleic (C 18.1) and linolenic acid (C 18.3), palmitic acid was the highest $(8.5-13.9 \%)$ while myristic acid was the least $(0.3-1.2 \%)$ in saturated acids profile. In addition to, Romero-Baranzini et al. (2006) mentioned that, P. ovata seeds contain $6.7 \%$ crude fats. In addition to, the oil from Plantago seeds had a high percentage of linoleic acid (40.6\%) and oleic acid $(39.1 \%)$ and a minor proportion of linolenic acid (6.9\%). Moreover, Dungait et al. (2008) studied the gas chromatogram of fatty acids extracted from $P$. media leaves. They found a high abundance of saturated $\mathrm{C} 16$ and unsaturated $\mathrm{C} 18$ fatty acids. Average percentage fatty acid contents for C16:0, C18:2 and C18:3 of leaves analyzed were $20 \%, 13 \%$ and $56 \%$, respectively. 
TABLE 2. Chemical constituents of fatty acids for $P$. major herbs.

\begin{tabular}{|l|c|}
\hline \multicolumn{1}{|c|}{ Chemical constituents of fatty acids } & $(\%)$ \\
\hline Lauric acid (C12:0) & 4.28 \\
\hline Myristic acid (C14:0) & 3.11 \\
\hline Myristoleic acid (C14:1) & 4.43 \\
\hline Palmitic acid (C16:0) & 15.44 \\
\hline Palmitoleic acid (C16:1) & 0.68 \\
\hline Margaric acid (C17:0) & 0.18 \\
\hline Margaolic acid (C17:1) & 0.10 \\
\hline Stearic acid (C18:0) & 2.62 \\
\hline Oleic acid (C18:1) & 15.56 \\
\hline Linoleic acid (C18:2) & 27.96 \\
\hline$\alpha$-linolenic acid(C18:3n6) & 0.72 \\
\hline Linolenic acid (C18:3n3) & 23.20 \\
\hline Arachidic acid (C20:0) & 0.62 \\
\hline Gadoleic acid (C20:1) & 0.40 \\
\hline Bahenic (C22:0) & 0.70 \\
\hline Un-saturated Fatty acid & 73.05 \\
\hline Saturated Fatty acid & 26.95 \\
\hline
\end{tabular}

Active ingredient from ethanolic extract of P. major herbs

Data presented in Table 3 noticed that active ingredient activity of $P$. major herbs contain $31.67 \mathrm{mg} / 100 \mathrm{~g}$ D.W. total phenols, $90.14 \mathrm{mg} / 100 \mathrm{~g}$ D.W. total flavonoids, $951.9 \mathrm{mg} / 100 \mathrm{~g}$ D.W. antioxidants activity, $143.3 \mathrm{mg} / 100 \mathrm{~g}$ D.W. total alkaloids, $15.23 \mathrm{mg} / 100 \mathrm{~g}$ D.W. total tannins, $15.68 \mathrm{mg} / 100 \mathrm{~g} \mathrm{D.W}$. total saponine and exhibited the presence of total terpenoid.

These results are in line with those (Salihoglu et al., 2013, Reslon et al., 2014, Mello et al., 2015 and Abd El-Gawad et al., 2015).

TABLE 3. Active ingredient from ethanolic extract of $\boldsymbol{P}$.major herbs.

\begin{tabular}{|l|c|}
\hline Active ingredient from ethanolic extract of $\boldsymbol{P}$. major & $\begin{array}{c}\text { mg/100g dry } \\
\text { extract }\end{array}$ \\
\hline Total phenols & 31.67 Gallic acid \\
\hline Total flavonoids & 90.14 Quercetin \\
\hline Antioxidants activity & $951.9 \mathrm{DPPH}$ \\
\hline Total alkaloids & 143.3 Atropine \\
\hline Total tannins & 15.23 Gallotannic acid \\
\hline Total saponine & 15.68 Diosganin \\
\hline Total terpenoid & Test $(+)$ \\
\hline
\end{tabular}

Egypt. J. Vet. Sci. Vol. 47, No. 1 (2016) 


\section{Identification and determination of phenols}

Data presented in Table 4 performed to identify and determine the major constituents of phenols by ethanolic extract of $P$. major, it is found that ethanolic extract of $P$. major comprised the biologically active phenolic compounds including syringic, protocatechol, chatechcol, euganal, gallic, catechin, salicylic, ellagic, cinnamic and chrysin.

The obtained results are in agreement with those reported by Khalil et al. (2007) found that $P$. afra contain phenolic compounds including sallicylic acid, pyrogallic acid, coumaric acid, ferulic acid, resorcinol, phenol, coumarin, vanillin, chlorogonic acid, cinnamic acid, hydroxyl benzoic and catechol. Similarly, Beara et al. (2009) found that found that Plantago species methanolic extract including $P$. argentea Chaix, P. holosteum Scop,. P. major L., $P$. maritima $\mathrm{L}$., and $P$. media L. contain flavonoids profile including luteolin-7-Oglucoside, apigenin-7-O-glucoside, luteolin, apigenin, rutin, and quercetin was identified. Also, Mohamed et al. (2011) found that P. major comprised the biologically active phenolic compounds including ferulic, caffeic, gallic acid and vanillic acids, in addition to flavonoid compounds, i.e., luteolin, kaempferol, rutin, naringenin and ferulic acid. In this respect, Jankovic et al. (2012) found that extract with $50 \%$ ethanol of the aerial parts of six Plantago contain flavonoid compounds fractions with different concentrations according to plantago species including luteolin-7-O-glucoside, apigenin-7-O-glucoside, luteolin, apigenin, rutin, mangiferin. In addition to, Amakura et al. (2012) found that seven phenolic compounds, among them, vanillic acid, plantamajoside, desrhamnosyl acteoside, and new phenylethanoid glycoside, were isolated from the ethyl acetate extract of Plantago herb (whole part of P. asiatica L.).

TABLE 4. Chemical constituents of phenols compounds for $P$. major .

\begin{tabular}{|l|c|}
\hline \multicolumn{1}{|c|}{ Chemical constituents of phenols compounds } & $(\%)$ \\
\hline Syringic & 0.1 \\
\hline Protocatechol & 23.7 \\
\hline Unknown & 5.5 \\
\hline Chatechcol & 6.7 \\
\hline Euganal & 20.4 \\
\hline Gallic & 9.5 \\
\hline Catechin & 12.9 \\
\hline Salicylic & 2.2 \\
\hline Ellagic & 10.8 \\
\hline Cinnamic & 1.3 \\
\hline Unknown & 4.0 \\
\hline Chrysin & 3.0 \\
\hline
\end{tabular}

Egypt. J. Vet. Sci. Vol. 47, No. 1 (2016) 
Biochemical assay

Effect of $P$. major plant extraction on rats injected with CCl4

As shown in Tables 5, 6 and 7, data revealed that the assessment of kidney (renal) and liver function impairment effect of carbon tetrachloride (CCl4) and the protective potential of $P$. major extract. Serum urea, uric acid and creatinine concentrations were studied to assess the renal functions while serum ALT, AST $\mathrm{ALPh}$, total protein, ALB and total bilirubin levels were determined to evaluate the hepatic functions. $\mathrm{CCl} 4$ induced significant elevations in these parameters when compared to control values.

\section{Serum glucose}

Regarding serum glucose, data mentioned that carbon tetrachloride-treated rats exhibited a significant increase in the levels of serum glucose $(146.71 \mathrm{mg} / \mathrm{dl})$ as compared to normal control $(79.08 \mathrm{mg} / \mathrm{dl})$ and extract of $P$. major herbstreated rats $(68.27 \mathrm{mg} / \mathrm{dl})$. The application of $P$. major extract groups before $\mathrm{CCl} 4$ injection exhibited significant reductions in the levels of serum glucose $(101.32 \mathrm{mg} / \mathrm{dl})$ as compared to $P$. major extract groups either with $(131.27 \mathrm{mg} / \mathrm{dl})$ or after $(135.91 \mathrm{mg} / \mathrm{dl}) \mathrm{CCl} 4$ injection.

The obtained results are in agreement with those reported by Atta et al. (2006) and Usoh et al. (2015), they observed the levels of serum glucose were increased with $\mathrm{CCl} 4$ treated.

On the other hand, Noor et al. (2000) found that $600 \mathrm{mg} / \mathrm{kg}$ dose of P. major water extract had a significant effect in reducing blood glucose level in diabetic rats. Also, Palmeiro et al. (2003) found that aqueous extract of P. australis leaves at $850 \mathrm{mg} / \mathrm{kg}$ decreased glucose serum levels in relation to control. Similarly, Ahmed et al. (2010) found that the blood glucose levels of treated groups of rats showed significant reduction after 7 weeks of treatment with $P$. psyllium. In addition, Shahat et al. (2012) showed the Serum glucose level showed significant increase in obese rats as compared with that in lean control rats. In contrast, significant decrease in serum glucose level was demonstrated in obese rats treated with Plantago seeds as compared with that in obese control rats.

\section{Lipid profile}

With respect to lipid profile, it is unveiled the groups of rats treated with Plantago extracts had a significant decrease in the levels of total cholesterol, triglyceride and low density lipoprotein cholesterol (LDL) with a significant increase in the level of in high density lipoprotein cholesterol (HDL) (149.08, $62.55,76.69$ and $52.25 \mathrm{mg} / \mathrm{dl}$ respectively) as compared to $\mathrm{CCl} 4$ treated groups $(178.19,161.38,91.64$ and $33.64 \mathrm{mg} / \mathrm{dl}$ respectively) and normal control (155.64, $153.87,87.14$ and $43.24 \mathrm{mg} / \mathrm{dl}$ respectively). The application of $P$. major extract groups before $\mathrm{CCl} 4$ injection exhibited significant reductions in these parameters 
except HDL (158.28, 86.65, 82.37 and $47.80 \mathrm{mg} / \mathrm{dl}$ respectively) as compared to $P$. major extract groups either with or after $\mathrm{CCl} 4$ injection.

The obtained results are in harmony with those reported by Atta et al. (2006) who found that oral administration of the methanolic extract $(1000 \mathrm{mg} / \mathrm{kg})$ of $P$. major seeds significantly decreased the levels of total cholesterol and triglyceride as compared to $\mathrm{CCl} 4$ treated rats and normal control. Also, Ahmed et al. (2010) found that cholesterol levels of treated groups of rats showed significant reduction after 7 weeks of treatment with P. psyllium.

TABLE 5. Effect of oral administration of $P$. major extract to rats injected with $\mathrm{CCl} 4$ on serum levels of glucose and lipid profile.

\begin{tabular}{|l|c|c|c|c|c|}
\hline \multirow{2}{*}{ Treatment } & \multirow{2}{*}{$\begin{array}{c}\text { Glucose } \\
(\mathbf{m g} / \mathbf{d l})\end{array}$} & $\begin{array}{c}\text { Chl } \\
(\mathbf{m g} / \mathbf{d l})\end{array}$ & $\begin{array}{c}\text { TG } \\
(\mathbf{m g} / \mathbf{d l})\end{array}$ & $\begin{array}{c}\text { LDL } \\
(\mathbf{m g} / \mathbf{d l})\end{array}$ & $\begin{array}{c}\text { HDL } \\
(\mathbf{m g} / \mathbf{d l})\end{array}$ \\
\hline $\begin{array}{l}\text { Negative control } \\
\text { (non-treated) }\end{array}$ & 79.08 & 155.64 & 153.87 & 87.14 & 43.24 \\
\hline CCl4(0.8ml/Kg.b.wt) & 146.71 & 178.19 & 161.38 & 91.64 & 33.64 \\
\hline $\begin{array}{l}P . \quad \text { major extract } \\
(100 \mathrm{mg} / \mathrm{Kg} . \text { b.wt) }\end{array}$ & 63.47 & 149.08 & 62.55 & 76.69 & 52.25 \\
\hline $\begin{array}{l}P . \text { major } \text { extract before } \\
\text { CCl4 }\end{array}$ & 101.32 & 158.28 & 86.65 & 82.37 & 47.80 \\
\hline $\begin{array}{l}P . \quad \text { major } \text { extract with } \\
\text { CCl4 }\end{array}$ & 131.27 & 161.39 & 102.96 & 84.29 & 40.55 \\
\hline $\begin{array}{l}P . \quad \text { major } \text { extract after } \\
\text { CCl4 }\end{array}$ & 135.91 & 165.87 & 121.71 & 87.08 & 35.20 \\
\hline New LSD at $0.05=$ & 14.31 & 3.08 & 6.81 & 1.87 & 7.03 \\
\hline
\end{tabular}

Liver functions

Our results showed that $\mathrm{CCl}_{4}$ markedly increased serum aminotransferases (AST and ALT), alkaline phosphatase (ALPh), total protein, albumin (ALB) and total bilirubin activities as indicators of hepatic injury since elevated levels of these hepatocellular enzymes are signs of $\mathrm{CCl}_{4}$-induced tissue damage which it record (44.32 U/L, 70.12 U/L, $312.59 \mathrm{U} / \mathrm{L}, 7.59 \mathrm{~g} / \mathrm{dl}, 4.93 \mathrm{~g} / \mathrm{dl}$, and $0.92 \mathrm{mg} / \mathrm{dl}$ respectively) as compared to normal control (13.43 U/L, $38.33 \mathrm{U} / \mathrm{L}, 147.61 \mathrm{U} / \mathrm{L}$, $7.21 \mathrm{~g} / \mathrm{dl}, 4.54 \mathrm{~g} / \mathrm{dl}$, and $0.53 \mathrm{mg} / \mathrm{dl}$ respectively) and Plantago extracts treated groups (11.39 U/L, 33.09 U/L, $141.23 \mathrm{U} / \mathrm{L}, 7.16 \mathrm{~g} / \mathrm{dl}, 3.51 \mathrm{~g} / \mathrm{dl}$ and 0.50mg/dl respectively). Moreover, pretreatment with $P$. major methanolic extract significantly decreased the $\mathrm{CCl}_{4}$-induced elevation of serum aminotransferases (ALT, AST) and ALPh activities and levels of serum total bilirubin, albumin and total bilirubin which may shows its action in preventing the acute tissue damage which it record (17.18 U/L, $40.92 \mathrm{U} / \mathrm{L}, 179.34 \mathrm{U} / \mathrm{L}, 7.25 \mathrm{~g} / \mathrm{dl}, 3.99 \mathrm{~g} / \mathrm{dl}$ and $0.55 \mathrm{mg} / \mathrm{dl}$ respectively) as compared to $P$. major extract groups either with or after CCl4 injection. The potential mechanism of this effect is by enhancing the activities of innate antioxidants. 
The obtained results are in agreement with those reported by Atta et al. (2006) who found that $P$. major is hepatoprotective activity against $\mathrm{CCl} 4$ toxicity. However, oral administration of the methanolic extract $(1000 \mathrm{mg} / \mathrm{kg})$ of $P$. major seeds significantly attenuated the CCl4-induced hepatotoxicity. Pretreatment with $P$. major methanolic extract significantly decreased the $\mathrm{CCl} 4$-induced elevation of serum aminotransferases (ALT, AST) and GGT activities. The levels of total bilirubin and albumin were also decreased. Also, Türel et al. (2009) showed that $P$. major extract $(25 \mathrm{mg} / \mathrm{kg})$ reduced the serum alanine amino transferase (ALT) and aspartate amino transferase (AST) levels compared to the treated rat of $\mathrm{CCl} 4$ induced hepatotoxicity. In addition, Usoh et al. (2015), showed that $\mathrm{CCl} 4$ treatment groups exhibiting significant decrease in liver functions including a significant increase in serum concentration of AST, ALT and ALPh compared to untreated rats.

TABLE 6. Effect of oral administration of $P$. major extract to rats injected with CCl4 on liver function.

\begin{tabular}{|l|c|c|c|c|c|c|}
\hline \multicolumn{1}{|c|}{$\begin{array}{c}\text { Treatment } \\
(\mathbf{m g} / \mathbf{K g . b . w t )}\end{array}$} & $\begin{array}{c}\text { AST } \\
(\mathbf{U} / \mathbf{L})\end{array}$ & $\begin{array}{c}\text { ALT } \\
(\mathbf{U} / \mathbf{L})\end{array}$ & $\begin{array}{c}\text { ALPh } \\
(\mathbf{U} / \mathbf{L})\end{array}$ & $\begin{array}{c}\text { Total } \\
\text { protei } \\
\mathbf{n}(\mathbf{g} / \mathbf{d l})\end{array}$ & $\begin{array}{c}(\mathbf{A L B}) \\
(\mathbf{g} / \mathbf{d l})\end{array}$ & $\begin{array}{c}\text { Total } \\
\text { bilirubin } \\
(\mathbf{m g} / \mathbf{d l})\end{array}$ \\
\hline Negative control (non-treated) & 13.43 & 38.33 & 47.61 & 7.21 & 4.54 & 0.53 \\
\hline CCl4 (0.8ml/Kg.b.wt) & 44.32 & 70.12 & 212.59 & 7.59 & 4.93 & 0.92 \\
\hline $\begin{array}{l}\text { P. major } \text { extract (100mg / Kg. } \\
\text { b.wt) }\end{array}$ & 11.39 & 33.09 & 41.23 & 7.16 & 3.51 & 0.50 \\
\hline P. major extract before CCl4 & 17.18 & 40.92 & 79.34 & 7.25 & 3.99 & 0.55 \\
\hline P. major extract with CCl4 & 28.39 & 57.41 & 107.98 & 7.33 & 4.38 & 0.61 \\
\hline P. major extract after CCl4 & 32.29 & 62.87 & 164.31 & 7.46 & 4.76 & 0.72 \\
\hline New LSD at 0.05 $=$ & 2.01 & 5.13 & 6.34 & 0.04 & 0.37 & 0.02 \\
\hline
\end{tabular}

\section{Kidney function}

With respect to Kidney function, it is unveiled significant increases in the levels of serum urea, uric acid and creatinine in the groups of rats treated with CCl4 alone (91.74, 7.29 and $0.193 \mathrm{mg} / \mathrm{dl}$ respectively) as compared to normal control $(49.36,4.94$ and $0.168 \mathrm{mg} / \mathrm{dl}$ respectively) and Plantago extracts treated groups $(44.67,4.63$ and $0.159 \mathrm{mg} / \mathrm{dl}$ respectively). The application of $P$. major extract groups before $\mathrm{CCl} 4$ injection exhibited significant reductions in these parameters $(59.05,5.52$ and $0.168 \mathrm{mg} / \mathrm{dl}$ respectively) as compared to $P$. major extract groups either with or after $\mathrm{CCl} 4$ injection.

The present study also revealed that the administration of $\mathrm{CCl} 4$ caused marked impairment in renal function alongside with significant oxidative stress in the kidney. Serum urea, creatinine, and uric acid concentrations were significantly higher in CCl4-treated rats. Urea is the main end product of protein

Egypt. J. Vet. Sci. Vol. 47, No. 1 (2016) 
catabolism. Serum creatinine elevation was caused by $\mathrm{CCl} 4$ due to altered kidney function. It is one of the waste products of the body which is passed into blood stream to be removed by kidney. P. major extract significantly decreased the elevated levels of serum urea, creatinine, and uric acid, which indicates that the $p$. major extract possibly protects kidney tissue against oxidative damages induced by $\mathrm{CCl} 4$ and indicates maintenance of renal function.

The obtained results are in the same line with those reported by Adewole et al. (2007), Al-Yahya et al. (2013) and Usoh et al. (2015), they showed that CCl4 treatment groups exhibiting significant decrease in kidney functions including a significant increase in serum concentration of urea, uric acid and creatinine compared to untreated rats.

Moreover, Sierra et al. (2002) found that $P$. psyllium reduced uric acid (10\%, significant difference). Also, Hong et al. (2011) found that $P$. asiatica L. extract pre-treated group showed decreases in the levels of serum urea and serum creatinine. Similarly, Mao-ye and Li-guo (2011) found that P. major L. seeds extract at $120 \mathrm{mg} / \mathrm{kg}$ body weight decrease serum urea in the mice blood.

Generally, the protective effect of plant extracts against CCl4 may be attributed to the presence of flavonoids, tannins, (Gilani and Janbaz, 1995), triterpenoids and steroids among the plant constituents that possess hepatoprotective effect (Gupta et al., 2004). Flavonoids are known to be antioxidants, free radical scavengers and antilipoperoxidants leading to hepatoprotection (Al-Qarawi et al., 2004). The active compounds of P. major for the observed effects have not been identified in the present study. Many compounds known to be beneficial against CCl4-mediated liver injury exert their protective action by toxin-mediated lipid peroxidation either via decreased production of $\mathrm{CCl} 4$ derived free radicals or through the antioxidant activity of the protective agents themselves (Gilani and Janbaz, 1995).

Cytogenetic studies

Abnormalities in bone marrow (somatic) and sperm (germ) cells

Tables 8 and 9 showed the number and mean percentage of abnormalities induced in control and treated animals. The percentage of aberrant cells in animals treated with CCl4 induced a high percentage of abnormalities $(p<0.01)$ in somatic and germ cells. While, the animal groups treated with ethanolic extracts of $P$. major was statistically non-significant in comparing to the control group. The crud extracts of $P$. major reduced the number of abnormalities when administered to $\mathrm{CCl} 4$ in all treatment. This reduction of abnormalities excluding gaps in bone marrow cells reached to $40 \%, 31 \%$ and $22 \%$ respectively (Table 8 ). While, for sperm abnormalities inhibition it reached to $66 \%, 45 \%$ and $31 \%$ before, with and after treatment with $P$. major respectively(Table 9). Our results showed that the crude extract of $P$. major is more effect when administered before and with $\mathrm{CCl} 4$ than that when treated after CCl4. Fig. 1 and 2 showing the different abnormalities in somatic and germ cells respectively. 
TABLE 7. Effect of oral administration of plant extracts to rats injected with CCl4 on kidney function.

\begin{tabular}{|l|c|c|c|}
\hline \multicolumn{1}{|c|}{ Treatment } & $\begin{array}{c}\text { Serum urea } \\
(\mathbf{m g} / \mathbf{d l})\end{array}$ & $\begin{array}{c}\text { Serum } \\
\text { uric acid } \\
(\mathbf{m g} / \mathbf{d l})\end{array}$ & $\begin{array}{c}\text { Serum } \\
\text { creatinine } \\
(\mathbf{m g} / \mathbf{d l})\end{array}$ \\
\hline Negative control (non-treated) & 49.36 & 4.94 & 0.168 \\
\hline CCl4(0.8ml/Kg.b.wt) & 91.74 & 7.29 & 0.193 \\
\hline P. major extract (100mg/Kg.b.wt) & 44.67 & 4.63 & 0.159 \\
\hline P. major extract before CCl4 & 59.05 & 5.52 & 0.168 \\
\hline P. major extract with CCl4 & 66.81 & 5.87 & 0.176 \\
\hline P. major extract after CCl4 & 72.41 & 6.29 & 0.187 \\
\hline New LSD at 0.05 $=$ & 4.61 & 0.27 & 0.007 \\
\hline
\end{tabular}

TABLE 8. Number and mean percentage of chromosomal aberrations induced after treatment with $\mathrm{CCl} 4$ and $\mathrm{CCl} 4$ with ethanolic crud extract from $P$. major in rat bone marrow cells.

\begin{tabular}{|c|c|c|c|c|c|c|c|c|c|}
\hline \multirow{3}{*}{$\begin{array}{c}\text { Treatments } \\
(\mathrm{mg} / \mathrm{kg} \mathrm{b.wt})\end{array}$} & \multicolumn{3}{|c|}{ Total Abnormal Metaphases } & \multicolumn{5}{|c|}{$\begin{array}{c}\text { No. of different types of } \\
\text { metaphases }\end{array}$} & \multirow{3}{*}{$\begin{array}{c}\text { Inhibitory } \\
\text { index } \\
\text { Excluding } \\
\text { Gaps }\end{array}$} \\
\hline & \multirow{2}{*}{ No. } & \multicolumn{2}{|c|}{$\operatorname{Mean}(\%) \pm \mathrm{SE}$} & \multirow[b]{2}{*}{ G. } & \multirow{2}{*}{$\begin{array}{c}\text { Frag. } \\
\text { and/or } \\
\text { Br. }\end{array}$} & \multirow[b]{2}{*}{ Del. } & \multirow[b]{2}{*}{ M.A. } & \multirow[b]{2}{*}{ Polyp. } & \\
\hline & & $\begin{array}{l}\text { Including } \\
\text { Gaps }\end{array}$ & $\begin{array}{c}\text { Excluding } \\
\text { Gaps }\end{array}$ & & & & & & \\
\hline I. control & 20 & $4.00 \pm 0.48$ & $2.20 \pm 0.40$ & 9 & 7 & 4 & 0 & 0 & - \\
\hline $\begin{array}{c}\text { II.CCl4 } \\
(0.8 \mathrm{ml} / \mathrm{kg})\end{array}$ & 103 & $20.60 \pm 0.52^{a}$ & $16.60 \pm 0.65^{\mathrm{a}}$ & 20 & 52 & 8 & 17 & 6 & - \\
\hline $\begin{array}{l}\text { III. P. major } \\
\text { (100) }\end{array}$ & 23 & $4.60 \pm 0.45$ & $2.40 \pm 0.52$ & 11 & 7 & 5 & 0 & 0 & - \\
\hline $\begin{array}{c}\text { IV. P. major } \\
\text { extract before } \\
\mathrm{CCl} 4\end{array}$ & 70 & $14.00 \pm 0.55^{\mathrm{ab}}$ & $10.80 \pm 0.48^{\mathrm{ab}}$ & 16 & 41 & 4 & 6 & 3 & 40 \\
\hline $\begin{array}{c}\text { V.P. major } \\
\text { extract with } \\
\text { CCl4 }\end{array}$ & 81 & $16.20 \pm 0.50^{\mathrm{at}}$ & $12.20 \pm 0.45^{\mathrm{ab}}$ & 20 & 44 & 8 & 4 & 5 & 31 \\
\hline $\begin{array}{c}\text { VI. P. major } \\
\text { extract after } \\
\quad \mathrm{CCl} 4\end{array}$ & 88 & $17.60 \pm 0.48^{\mathrm{ab}}$ & $13.40 \pm 0.50^{\mathrm{ab}}$ & 19 & 50 & 7 & 8 & 4 & 22 \\
\hline
\end{tabular}

Total number of examined metaphases 500 (5 animals/group), G.: Gap, Frag.: Fragments, Br.: Breaks Del.: Deletions , M.A.: Multiple aberrations, Polyp: Polyploidy.

a: Significant compared to control $(\mathrm{p}<0.01)$, b: Significant compared to CCl4 treatment $(\mathrm{p}<0.01, \mathrm{t}$ test).

Egypt. J. Vet. Sci. Vol. 47, No. 1 (2016) 

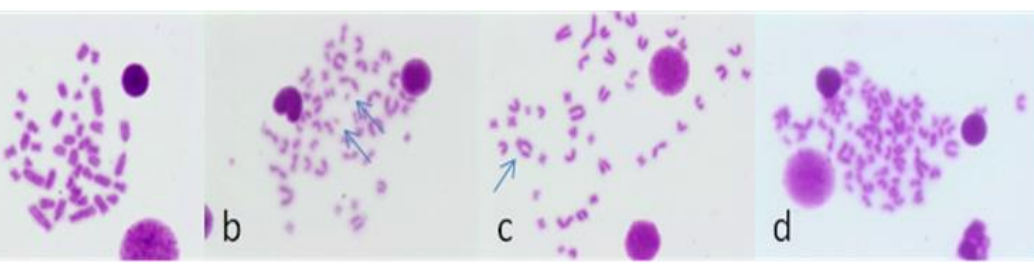

Fig.1. Chromosomal aberrations in rat bone marrow cells after treatment with CCL4 with ethanol crud extract of $P$. major showing, a) Normal, b) Fragments, c) Break and d) Polyploidy.

TABLE 9. Number and mean percentage of sperm abnormalities induced in rat after treatment with $\mathrm{CCl} 4$ and with ethanolic crud extract from $P$. major.

\begin{tabular}{|c|c|c|c|c|c|c|c|c|}
\hline \multirow{2}{*}{$\begin{array}{c}\text { Treatments } \\
\text { Mg/kg b.wt. }\end{array}$} & \multicolumn{2}{|c|}{ Abnormal sperms } & \multicolumn{3}{|c|}{$\begin{array}{c}\text { No. of different types of sperm head } \\
\text { abnormalities }\end{array}$} & $\begin{array}{c}\text { Inhibitory } \\
\text { index }\end{array}$ \\
\hline I. Control & 113 & $2.26 \pm 0.50$ & 31 & 4 & 61 & 10 & 7 & - \\
\hline $\begin{array}{c}\text { II.CCl4 } \\
(0.8 \mathrm{ml} / \mathrm{kg})\end{array}$ & 536 & $10.72 \pm 0.56^{\mathrm{a}}$ & 75 & 56 & 206 & 146 & 53 & - \\
\hline $\begin{array}{c}\text { III. } \text { P. major } \\
(100)\end{array}$ & 117 & $2.34 \pm 0.48$ & 28 & 7 & 65 & 12 & 5 & - \\
\hline $\begin{array}{c}\text { IV. } P . \text { major } \\
\text { extract before } \\
\text { CCl4 }\end{array}$ & 257 & $5.14 \pm 0.72^{\text {ab }}$ & 67 & 31 & 113 & 32 & 14 & 66 \\
\hline $\begin{array}{c}\text { V. } \text { P. major } \\
\text { extract with } \\
\text { CCl4 }\end{array}$ & 351 & $7.02 \pm 0.44^{\text {ab }}$ & 85 & 35 & 151 & 54 & 26 & 45 \\
\hline $\begin{array}{c}\text { VI. } P . \text { major } \\
\text { extract after } \\
\text { CCl4 }\end{array}$ & 405 & $8.10 \pm 0.58^{\text {ab }}$ & 101 & 47 & 148 & 78 & 31 & 31 \\
\hline
\end{tabular}

NO of examined sperms 5000 (1000/animal, 5 animals/group)

a: Significant compared to vehicle control $(\mathrm{p}<0.01)$, b: Significant compared to CCl4 treatment $(\mathrm{p}<0.01, \mathrm{t}$-test $)$ 


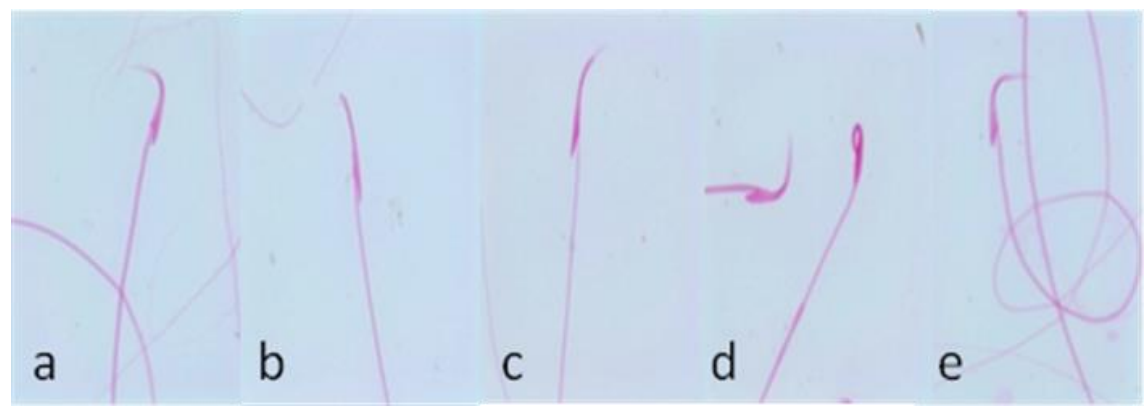

Fig.2. Sperm abnormalities in rat after treatment with $\mathrm{CCl} 4$ and with ethanol crud extract of $P$. major showing, a) Normal, b) Straight and without hook, c) Banana, d) Amorphous and e) Coiled tail.

Genotoxic activities of $\mathrm{CCl} 4$ have been reported in various assays. As for clastogenic effect of $\mathrm{CCl} 4$ the micronucleus assay in vivo was widely employed (Suzuki et al., 1997 and Crebeli et al., 1999). CCl4 was confirmed to cause cancer in rodents after prolonged exposure to CCl4 (Westbrook- Collins et al., 1990). Positive clastogenic or aneugenic results after treatment with of $\mathrm{CCl} 4$ were found in human metabolically competent cell lines, MCL-5 CYP which expresses cDNA encoding the human CYP1A1, and h2E1 cell lines containing cDNA for CYP2E1 (Doherty et al., 1996). Carbon tetrachloride in combination with chlordecone was genotoxic using the in vivo - in vitro animal model and a battery of biochemical assays to measure the DNA repair in the rat hepatocytes (Ikegwuonu and Mehendale, 1991). Because of long-lived tissue contacting different organs and organic systems, and that they have a potential to accumulate DNA lesions (Carrano and Natarajan, 1988) the peripheral lymphocytes are considered to be suitable for in vivo assays (Rojas et al., 1992). A significant increase of $\operatorname{SCE}(p<0.05, p<0.001)$ in sheep peripheral lymphocytes after $\mathrm{CCl} 4$ treatment in both assays i.e. with and without protective agent administration (Dianovsk and Ivikova, 2001). These previous studies are in the same line with our study which we found that administration $\mathrm{CCl} 4$ at $0.8 \mathrm{ml} / \mathrm{kg}$ b.w. to rat in vivo induced a significant increase on chromosomal aberrations and sperm abnormalities compared to negative control.

Antigenotoxicity of ethanolic extracts of $P$. major was established in bone marrow and sperm cells in CCl4 treated rat. Ethanolic extracts of $P$. major at a dose of $100 \mathrm{mg} / \mathrm{kg}$ b.w. had no apparent genotoxic effect, as the proportion of aberrant cells was not significantly different from that of the negative control in both somatic and germ cells, whereas conversely, it displayed significant antigenotoxic activity against $\mathrm{CCl} 4$ induced mutagenesis in bone marrow and sperm cells. CCl4, an extensively studied hepatotoxin is converted into its metabolites such as $\mathrm{CCl} 3$ radicals which are involved in the liver pathogenesis including cirrhosis, genotoxicity of hepatic tissue and hepatic carcinoma (Khan et al., 2012). El-Souda et al. (2014) demonstrated that P. albicans Egypt. J. Vet. Sci. Vol. 47, No. 1 (2016) 
phytoconstituents play a protective role against genotoxicity of the drug cyclophosphamide in mouse bone marrow cells.

Methanolic and ethanolic extracts of $P$. major have potential to be used as an alternative or adjunct treatment to reduce inflammation-mediated cell injury following APAP toxicity (Hussan et al., 2015).

P. major is one of the most studied plants. Most of its components and the pharmacological action of some of them are well known (Velasco-Lezama et al., 2006). It is possible that acids known to be contained in the plant (caffeic, ferulic, chlorogenic, ursolic and oleanic acids), with proven antitumor activity in vitro (Liu, 1995). P. major also contains flavonoids namely, luteoline, apigenin, hispidulin, baicalein, etc., known for their capability of inducing carcinoma cell death (Matsuzaki et al., 1996). Galvez et al. (2003) reported that Plantago extracts have growth inhibitory and cytotoxic effects of breast adenocarcinoma and melanoma cell lines and these preliminary results could be justified by the cytotoxic activity of the flavone, luteolin-7-O- $\beta$-glucoside, the major flavonoid in Plantago species.

Our results showed that $P$. major ethanolic extracts have the ability to reduce DNA damage induce in somatic and germ cells before, with and after treatment with CCl4. These results are in agreement with Atta et al. (2006) and Turel et al. (2009) they reported that $P$. major has a hepatoprotective effect when administered prior to CCl4 exposure. While, Hussan et al. (2015) reported that administration of $P$. major after rat liver injury exposed to acetaminophen reduced this damage.

We speculate that $P$. major mediate their chemopreventive effects against $\mathrm{CCl} 4$ either via decreased production of $\mathrm{CCl} 4$ derived free radicals or through the antioxidant activity of the protective agents themselves (Oto et al., 2011, Mello et al., 2015 and Farag et al ., 2015).

In conclusion, ethanolic extracts of $P$. major proved to be nontoxic and to exhibit hepatoprotective and antigenotoxic potential.

\section{References}

Abd El-Gawad, A. M., Ibrahim, A. M., Mohamed, E. A. and Deweeb, M. R. (2015) Phytotoxicity of three Plantago species on germination and seedling growth of hairy beggarticks (Bidens pilosa L.). Egyptian journal of basic and applied sciences, 2 , 303-309.

Adewole, S.O., Salako, A.A., Doherty, O.W. and Naicker, T. (2007) Effect of melatonin on carbon tetrachloride-induced kidney injury in Wistar rats. Afr J Biomed Res., 10, 153-164. 
Adewole ,S.O., Ojo, S.K., Adenowo, T.K., Salako, A.A., Naicker, T. and Ojewole, J.A.O. (2012) Effects of Ficus exasperata Vahl. (Moraceae) leaf aqueous extract on the renal function of streptozotocin-treated rats. Folia Morphologica, 71, 1-9.

Ahmed, I., Naeem, M., Shakoor, A., Ahmed, Z. Muhammad, H. and Iqbal N. (2010) Investigation of Anti-diabetic and Hypocholesterolemic Potential of Psyllium Husk Fiber (Plantago psyllium) in Diabetic and Hypercholesterolemic Albino Rats. World Academy of Science, Engineering and Technology, 37, 1229-1233.

Allain, C.C., Poon, L.S., Chan, C.S. and Richmond, W. (1974) Enzymatic determination of total serum cholesterol. Clin. Chem., 20, 470-75.

Al-Qarawi, A.A., Mousa, H.M, Ali, B.H., Abdel-Rahman, H. and El-Mougy, S.A. (2004) Protective effect of extracts from dates (Phoenix dactylifera L.) on carbon tetrachloride-induced hepatotoxicity in rats. Intern. J. Appl. Res. Vet. Med., 2(3): 176-180.

Al-Yahya M., Mothana R. and Al-Said M. (2013) Attenuation of CCl4-induced oxidative stress and hepatonephrotoxicity by Saudi Sidr honey in rats. Evidence-Based Complementary and Alternative Medicine, 10. doi: 10.1155/2013/569037.569037

Amakura, Y., Yoshimura, A., Yoshimura, M. and Yoshida T. (2012) Isolation and characterization of phenolic antioxidants from Plantago Herb. Molecules, 17, 5459-5466.

A.O.A.C. (2005) Official Methods of Analysis of AOAC international 18th Ed. Association of Official Analytical Chemists, Washington, D.C., pp. 1-14.

Atta, A.H., Nasr, S.M. and Mouneir, S.M. (2005) Antiulcerogenic effect of some plants extracts. Natural Product Radiance, 4, 258-263.

Atta, A.H., Nasr, S.M. and Mouneir, S.M. (2006) Potential protective effect of some plant extracts against carbon tetrachloride-induced hepatotoxicity. Afr. J. Tradit. Complement Altern. Med., 3 (3), 1-9.

Aura, A.M., Forssel, P., Mustranta, A. and Poutanen, K. (1995) Transesterification of soy lecithin by lipase and phospholipase. J. Am. Oil Chem. Soci., 72, 1375-1379.

Beara I. N., Lesjak M. M., Jovin D., Balog K. J., Anackov G. T., Orcic D. Z. and Mimica-Dukic N. M. (2009). Plantain (plantago L.) species as novel sources of flavonoid antioxidants. Journal of Agricultural and Food Chemistry, 57, 9268-9273.

Beara, I.N., Orcic, D.Z., Lesjak, M.M., Mimica-Dukic, N.M., Pekovic, B.A. and Popovic, M.R. (2010) Liquid chromatography/tandem mass spectrometry study of anti-inflammatory activity of Plantain (Plantago L) species. Journal of Pharmaceutical and Biomedical Analysis 52, 701-706.

Beara, I.N., Lesjak, M.M., Orcic, D.Z., Simin. N.D., Cetojevi-Simin, D.D., Bozin, B.N. and Mimica-Duki, N.M. (2012) Comparative analysis of phenolic profile, antioxidant, anti-inflammatoryand cytotoxic activity of two closely-related Plantain species: Plantago altissima L. and Plantago lanceolata L. Food Science and Technology, 47 (1), 64-70.

Egypt. J. Vet. Sci. Vol. 47, No. 1 (2016) 
Bhadauria, M., Nirala, K.S. and Shukla, S. (2008) Multiple treatment of Propolis ameliorates carbon tetrachloide induced liver injuries in rats. Food and Chemical Toxicology, 46, 2703-2712.

Blumenthal, M., Busse ,W.R., Goldberg, A., Gruenwald, J., Hall, T., Riggins, C.W., Rister, R.S., Klein, S. and Rister, R.S. (2000) Plantain. Texas: American Botanical Council, Boston: Integrative Medicine Communications. Adapted from: The Complete German Commission E Monographs-Therapeutic Guide to Herbal Medicines.

Brand-Williams, W., Cuvelier, M.E. and Berset, C. (1995) Use of a free radical method to evaluate antioxidant activity. Food Sci Technol LWT, 28 (1), 25-30

Çam, M. and Hışıl, Y. (2010) Pressurised water extraction of polyphenols from pomegranate peels. Food Chem., 123 (3), 878-885.

Carrano, A. V. and Natarajan, A. T. (1988). Consideration for population monitoring using cytogenetic techniques. Mutat. Res., 204, 397-406.

Chiang, L., Chiang, W., Chang, M. and Lin, C. (2003) In vitro cytotoxic, antiviral and immunomodulatory effects of Plantago major and Plantago asiatica. Am. J. Chinese Med., 31 (2), 225-234.

Crebeli, R., Carere, A., Leopardi, P., Conti, L., Fassio, F., Raiteri, F., Barone, D., Ciliutti, P., Cinelli, S. and Vericat, J.A. (1999) Evaluation of 10 aliphatic halogenated hydrocarbons in the mouse bone marrow micronucleus test. Mutagenesis, 14, $207-215$.

Da Silva, A.L.G., Lieber, S.R., Ruiz, M.A. and De Souza, C.A. (1997) Micronucleus monitoring to assess the human occupational exposure to organochlorides. Environ. Mol. Mutagen., 29, 46-52

Daniel, H.D. and George, C.M. (1972) Peach seed dormancy in relation to indogenous inhibitors and applied growth substances. J. Amer. Soc. Hort. Sci., 97, 651-654.

Dhar, M.K., Kaul, S., Sareen, S. and Koul, A.K. (2005) Plantago Ovata: genetic diversity, cultivation, utilization and chemistry. Plant Genetic Resources., 3, 252-263.

Dianovsk, J. and Ivikova, K. (2001) CCL4 induced genotoxicity and protective effect of antioxidants after in vivo administration to sheep. Acta Vet. Brno., 70, 467-472

Díez-Láiz, R., García-Vieitez, J.J.M., José D.L., Matilde S.V., Sahagún, P.A.M., Calle-Pardo, A.P. and Nélida F.M. (2015) Evaluation of the Association Metformin: Plantago ovata Husk in Diabetic Rabbits. Journal of Diabetes Research, 167526.

Doherty, A.T., Ellard, S., Parry, E.M. and Parry, J.M. (1996) An investigation into the activation and deactivation of chlorinated hydrocarbons to genotoxins in metabolically competent human cells. Mutagenesis, 11, 247-274.

Dokuparthi, S.K. and Manikanta, P., (2015) Phytochemical and pharmacological studies on Chrysanthemum coronarium L.: A Review. Journal of Drug Discovery and Therapeutics (Source: American Chemical Society), 3 (27), 11-16. 
Dungait, J.A.J., Docherty, G., Straker, V. and Richard, P.E. (2008) Interspecific variation in bulk tissue, fatty acid and monosaccharide d13C values of leaves from a mesotrophic grassland plant community. Phytochem., 69, 2041-2051.

El-Sheikh, D.M. (2014) Rheological characteristics of Arabic gum suspension and Plantago seeds mucilage. J. Am. Sci., 10 (11), 18-24.

El-Souda, S.S. Reda S.M., Mona M.M., Maha A.F., Zeinab M. H. and Ayman A. F. (2014) Antimutagenicity and phytoconstituents of Egyptian Plantago albicans L. Asian Pac. J. Trop. Dis., 4 (Suppl 2), S946-S951.

Farag, N.F., Enas H. A., Shadia M. A. and El-Sayeda, A. (2015) Protective Effect of Chrysanthemum Pacificum Against CCl4-Induced Injury on the Human Hepatoma Cell Line (Huh7). J. Pharm. Sci. Res., 7 (9), 633-639.

Ferrazzano, G.F., Cantile, T., Roberto, L., Ingenito, A., Catania, M.R., Roscetto, E., Palumbo, G., Zarrelli, A. and Pollio, A. (2015) Determination of the In vitro and in vivo antimicrobial activity on salivary streptococci and lactobacilli and chemical characterisation of the phenolic content of a Plantago lanceolata infusion. BioMed Research International, Article ID 286817, 8 pages.

Fossati, P. and Principe, L. (1982) Enzymatic colorimetric method to determination triglycerides. Clin. Chem., 28, 2077.

Galvez, M., Martin-Cordero, C., Lopez-Lazaro, M., Cortes, F. and Ayusa, M.J. (2003) Cytotoxic effect of Plantago spp. on cancer cell lines. Journal of Ethnopharmacology, 88, 125-130.

Ganatra, S.H., Durge, S.P. and Patil, S.U. (2012) Preliminary Phytochemical Investigation and TLC Analysis of Ficus racemosa Leaves. JCPR, 4(5), 2380-2384.

Gilani, A.H. and Janbaz, K.H. (1995) Preventive and curative effects of Artemisia absinthium on acetaminophen and CCl4-induced hepatotoxicity. Gen. Pharmacol., 26, 309-315.

Guenther, E. (1960) "The Essential Oils", $4^{\text {th }}$ ed., Vol. I, II. D. Van Nostrand Co., INC., New York.

Gupta, M., Mazumder, U.K., Kumar, R.S., Sivakumar, T. and Vamsi, M.L. (2004) Antitumor activity and antioxidant status of Caesalpinia bonducella against Ehrlich ascites carcinoma in Swiss albino mice. J. Pharmacol Sci., 94, 177-184.

Hong, C.O., Hong, S.T., Koo, Y.C., Lee, J.Y., Lee, Y., Ha, Y.M. and Lee, K.W. (2011) Protective Effect of Plantago asiatica L. Extract Against Ferric Nitrilotriacetate (FeNTA) Induced Renal Oxidative Stress in Wistar Rats. Journal of Food Hygiene and Safety, 26 (2),107-113.

Hu, J. L., Nie, S.P., Wu., Q. M., Li, C., Fu, Z. H., Gong, J., Cui, S.W., and Xie, M.Y. (2014) Polysaccharide from seeds of Plantago asiatica L. affects lipid metabolism and colon microbiota of mouse. Journal of Agricultural and Food Chemistry, 62 (1), 229-234.

Egypt. J. Vet. Sci. Vol. 47, No. 1 (2016) 
Hussan, F., Basah, R. H. O., Yusof, M. R. M., Kamaruddin, N. A. and Othman, F. (2015) Plantago major treatment enhanced innate antioxidant activity in experimental acetaminophen toxicity. Asian Pac. J. Trop. Biomed., 5 (9), 728-732.

Ikegwuonu, F. I. and Mehendale, H. M. (1991) Biochemical assessment of the genotoxicity of the in vivo interaction between chlordecone and carbon tetrachloride in rat hepatocytes. J. Appl. Toxicol., 11, 303-310.

Jackson, M.L. (1958) Soil Chemical Analysis Constable \& Co. Ltd. London PP.498

Jackson, M.L. (1967) Soil Chemical Analysis. Printice-Hall Inc. Englewood Cliffs-N.S.

Jankovi, T., Zduni, G., Beara, I., Balog, K., Pljevljaku, D., Stesevi, D. and Savikin, K. (2012) Comparative study of some polyphenols in Plantago species. Biochemical Systematics and Ecology., 42, 69-74.

Javed, M. Mahmud, S. Ali, S. and Aman, T. (2003) Fatty acid and lipid composition of Plantago ovata. Pak. J. Sci. Ind. Res., 46 (3), 213-214.

Jayaraman (1985) Postharvest biological control. Wiely Eastern Limited. New Delhi.

Khalil, M.Y., Moustafa, A.A. and Naguib, N.Y. (2007) Growth phenolic compounds and antioxidant activity of some medicinal plants growth under organic farming condition. World J. Agric. Sci., 3 (4), 451-457.

Khan, R.A., Khan, M.R. and Sahreen , S. (2010). Evaluation of Launaea procumbens use in renal disorders: a rat model. J Ethanopharmacol, 128, 452-461.

Khan, R.A., Khan, M.R. and Sahreen, S. (2011) Protective effect of Sonchus asper extracts against experimentally-induced lung injuries in rats: A novel study. Experimental and Toxicologic Pathology. doi:10.1016/j.etp. 01.007.

Khan ,R.A., Khan ,M.R. and Sahreen, S. (2012) CCl4-induced hepatotoxicity: protective effect of rutin on $\mathrm{p} 53, \mathrm{CYP} 2 \mathrm{E} 1$ and the antioxidative status in rat. $B M C$ Complementary and Alternative Medicine, 12,178-179.

Liu, J. (1995) Pharmacology of oleanic acid and ursolic acid. Journal of Ethnopharmacology, 49, 57-68.

Liu, L., Ho, P., Zhou, Y., Hocart, C. and Zhang, R. (2002) Fatty acid profiles of leaves of nine edible wild plants: An Australian study. J. Food Lipids, 9, 65-70.

Madrigal-Bujaidar, E., Diaz Barriga, S., Cassani, M., Molina, D. and Ponce, G. (1998) In vivo and in vitro induction of sister-chromatid exchanges by nordihydroguaiaretic acid. Mutat. Res., 412,139-144.

Mao-ye, W. and Li-guo, A. (2011) Effects of Plantago major L. seeds extract on endurance exercise capacity in mice. Journal of Medicinal Plants Research 5 (9), 1659-1663.

Matsuzaki, N. Kurokawa, S. Terai, Y. Matsumura, N. Kobayashi and K. Okita, (1996) Cell death induced by baicalein in human hepatocellular carcinoma cell lines. Japanese Journal of Cancer Research, 87, 170-177. 
Mello, J.C., Gonzalez, M. V. D., Moraes, V. W. R., Prieto, T., Nascimento, O.R. and Rodrigues, T. (2015) Protective Effect of Plantago major Extract against t-BOOHInduced Mitochondrial Oxidative Damage and Cytotoxicity. Molecules, 20, 17747-17759.

Merfort, I., Wray, V., Barakat, H.H., Hussen, S.A.M., Nawwar, M.A.M. and Willuhan, G. (1997) Flavonol triglycerides from seeds of Nigella sativa. Phytochem., 46 (2), 359-363.

Miller, G.L. (1959) Use of dinitrossalicylic acid reagent for determination of reducing sugars. Anal Chem., 31, 426-428.

Mohamed, I. K. , Osama, M. A.F., Samiha M. A. E. and Zahrat E.O. M.(2011) Biochemical studies on Plantago major L. and Cyamopsis tetragonoloba L. International Journal of Biodiversity and Conservation, 3 (3), 83-91.

Naguib, N.Y.M. (2011) Organic vs chemical fertilization of medicinal plants: a concise review of researches. Adv. Environ. Biol., 5 (2), 394-400.

Noor, H., Juing, M., Chee, B.J., Kueh, B.L. and Othman, Z. (2000) Medicinal Properties of Plantago major: Hypoglycaemic and Male Fertility Studies. Pertanika J. Trop. Agric. Sci., 23 (1), 29-35.

Ogeturk, M., Kus, I., Colakoglu, N., Zararsiz, I., Ilhan, N. and Sarsilmaz M. (2005) Caffeic acid phenethyl ester protects kidneys against carbon tetrachloride toxicity in rats. J. Ethnopharmacol., 97, 273-80.

Oto, G., Suat, E., Hulya, O., Halit, D., Semih, Y., Abdulkadir, L., Ismet, B. and Baris, K. (2011). Plantago major protective effects on antioxidant status after administration of 7,12-Dimethylbenz(a)anthracene in rats. Asian Pacific Journal of Cancer Prevention, 12, 531-535.

Palmeiro, N.M.1., Almeida, C.E., Ghedini, P.C., Goulart ,L.S., Pereira, M.C., Huber, S., da Silva, J.E. and Lopes, S. (2003) Oral subchronic toxicity of aqueous crude extract of Plantago australis leaves. J Ethnopharmacol., 88 (1), 15-8.

Ponce-Macotela, M., Navarro-Alegria, I., Martınez-Gordillo, M.N. and AlvarezChacon, R. (1994) In vitro antigiardiasic activity of plant extracts. La Revista de Investigacion Clinica, 46, 343-347.

Preethi ,K.C. and Kuttan R. (2009) Hepato and reno protective action of Calendula officinal is L. flower extract. Exp. Biol., 47, 163-168.

Pregl, F. (1945) "Quantitative Organic Micro-Analysis", $4^{\text {th }}$ ed., J \& A. Churchill Ltd. London.

Reslon, W., Osińska, E., Geszprych, A., Tokarska, J. and Orliński, P. (2014) Effect of chosen agronomic factors on the yield and raw material quality of three populations of greater plantain (Plantago Major L.). International Scientific Publications: Agriculture and Food, 2 (1), 257-266. 
Rojas, E., Montero, R., Herrera, L. A., Sordo, M., Gonsebatt, M. E., Rodriguez, R. and Ostrosky-Wegman, P. (1992) Are mitotic index and proliferation kinetics reproducible endpoints in genetic toxicity testing? Mutat. Res. 282, 283-286.

Romero-Baranzini, A.L., Rodriguez, O.G., Yanez-Farias, G.A., Barron-Hoyos, J.M. and Rayas-Duarte, P. (2006) Chemical, Physicochemical, and Nutritional Evaluation of Plantago (Plantago ovata Forsk). Cereal Chem., 83 (4), 358-362.

Sahreen, S., Khan, M.R. and Khan, R.A. (2011) Hepatoprotective effects of methanolic extract of Carissa opaca leaves on CCl4-induced damage in rat. BMC Complementary and Alternative Medicine, 11 (48), 10-15

Sakanaka S., Tachibana Y. and Okada Y. (2005) Preparation and antioxidant properties of extracts of Japanese persimmon leaf tea (kakinohacha). Food Chemistry, 89, $569-575$.

Salihoglu, E.M., Akaydin, G., Can, E.C. and Akaydin, S.Y. (2013) Evaluation of antioxidant activity of various herbal folk medicines. J. Nutr. Food Sci., 5, 1-9.

Shad, A.A., Shah, H.U. and Bakht, J. (2013) Ethnobotanical assessment and nutritive potential of wild food plants. The Journal of Animal \& Plant Sciences, 23 (1), 92-97.

Shahat, A.A., Ahmed, H.H., Hammouda, F.M. and Ghaleb, H. (2012). Regulation of obesity and lipid disorders by Foeniculum vulgare extracts and Plantago ovata in high-fat diet-induced obese rats. American Journal of Food Technology, 7, 622-632.

Shamsa, F., Hamidreza M., Rouhollah G. and Mohammadreza V. (2008). Spectrophotometric determination of total alkaloids in some Iranian medicinal plants. Thai J. Pharm. Sci., 32, 17-20.

Shenoy, K.A., Somayaji, S.N. and Bairy, K.L. (2001) Hepatoprotective effects of Ginkgo biloba against carbon tetrachloride induced hepatic injury in rats. Ind $J$ Pharmacol, 33, 260-266.

Sierra, M., Garcia, J.J., Fernandez, N., Diez, M. J., Calle, A.P. and Group, F. (2002) Therapeutic effects of psyllium in type 2 diabetic Patients . Eur. J. Clin. Nut., 55, 830-842.

Smith, F., Gilles, M.A., Hamilton, J.K. and Godess, P.A. (1956) Colorimetric method for determination of sugar and related substances. Anal. Chem., 28, 350-358.

Smullen ,J., Koutsou, G.A., Foster H.A., Zumbé, A. and Storey, D.M. (2007) The antibacterial activity of plant extracts containing polyphenols against streptococcus mutans. Caries Res, 41 (5), 342-9.

Snedecor, G. W. and Cochran, W.G. (1980) "Statistical Methods", $7^{\text {th }}$ ed., The Iowa State Univ. Press. Ames., Iowa, U.S.A., 593 p.

Sreelatha ,S., Padma, P.R. and Umadevi, M. (2009) Protective effects of Coriandrum sativum extracts on carbon tetrachloride-induced hepatotoxicity in rats. Food and Chemical Toxicology, 47, 702-708. 
Stanisavljevic, I.T., Stojicevic, S.S., Velickovic, D.T., Lazic, M.L. and Veljkovic, V.B. (2008). Screening the antioxidant and antimicrobial properties of the extracts from Plantain (Plantago major L.) leaves. Separation Science and Technology, 43, 3652-3662.

Suzuki, H., Hirano, N., Watanabe, C. and Tarumoto, Y. (1997). Carbon tetrachloride does not induce micronucleus in either mouse bone marrow or peripheral blood. Mutat. Res., 394, 77-80.

Sweeney, J.P. and Martin, M. (1958) Determination of chlorophyll and pheophytin in broccoli heated by various procedures. Journal of Food Science, 23 (6), 635-647.

Tafazoli, M., Beaten, A., Geerlings, P. and Kirsch-Volders, M. (1998) In vitro mutagenicity and genotoxicity study of a number of short-chain chlorinated hydrocarbons using the micronucleus test and the alkaline single cell gel electrophoresis technique (Comet assay) in human lymphocytes: a structural activity relationship (QSAR) analysis of the genotoxic and cytotoxic potential. Mutagenesis, 13, 115-126.

Tafazoli, M. and Kirsch-Volders, M. (1996) In vitro mutagenicity and genotoxicity study of 1,2-dichlorethylene, 1,1, 2- trichlotethane, 1-3 dichlorpropane, 1,1,3trichloropropene, using the micronucleus test and the alkaline cell gel electrophoresis technique (comet assay) in human lymphocytes. Mutat. Res., 371, 185-202.

Tietz, N.W. (1976a) Fundamentals of Clinical Chemistry W.B. Saunders Co., Philadelphia, p.243.

Tietz, N.W. (1976b) Fundamentals of Clinical Chemistry W.B. Saunders Co., Philadelphia. pp. 999-1002.

Tietz., N.W. (1986) Textbook of clinical chemistry. WB Saunders, Philadelphia, pp. 1271-1281.

Tietz, N.W. (1990) "Clinical Guide To Laboratory Tests", $2^{\text {nd }}$ ed. Philadelphia: WB Saunders. 566.

Tirkey, N.G., Kaur ,G., Vij, K. and Chopra, K. (2005) Hesperidin, a citrus bioflavonoid, decreases the oxidative stress produced by carbon tetrachloride in rat liver and kidney. BMC Pharmacol, 5, 15-21.

Trinder, P. (1969) Determination of glucose in blood using glucose-oxidase with an alternative oxygen acceptor. Ann. Clin. Biochem, 6, 24-27.

Türel, I., Ozbek, H., Erten, R., Oner, A.C., Cengiz, N. and Yilmaz, O. (2009) Hepatoprotective and anti-inflammatory activities of Plantago major L. Indian J. Pharmacol. 41, 120-124.

Uematsu ,Y., Hirata, K. and Saito K. (2000) Spectrophotometric determination of saponin in Yucca extract used as food additive. J. AOAC Int. 83, 1451-1454.

Usoh, I.F. and Akpan, H.D. (2015) Antinephrotoxic and hepatoprotective potential of combined $80 \%$ ethanolic leaves extracts of Gonglonema latifolium and Ocimum gratissimum against carbon tetrachloride-induced toxicity in rats. Journal of Science, 5 (12), 1149-1155.

Egypt. J. Vet. Sci. Vol. 47, No. 1 (2016) 
Vassault, A., Grafmeyer, D., Naudin, C., Dumont, G., Bailly, M. and Henny J. (1986) Protocole de validation de techniques. Ann. Biol. Clin., 44, 686-745.

Velasco-Lezama, R., Aguilar, R.T., Ramos , R.R., Avila, E.V. and Gutierrez Ma, S.P. (2006) Effect of Plantago major on cell proliferation in vitro. Journal of Ethnopharmacology, 103 (1), 36-42.

Walters, M.I. and Gerarde, H.W. (1970) An ultramicromethod for the determination of conjugated and total bilirubin in serum or plasma. Microchemical Journal, 15 (2), 231-243.

Weber, L.W., Boll, M. and Stampfl, M. (2003) Hepatotoxicity and mechanism of action of haloalkanes: carbon tetrachloride as a toxicological model. Crit Rev Toxicol, 33,105-136.

Weenen, H., Nkunya, M. H .H., Bray, D. H., Mwasumbi ,L. B., Kinabo, L .S. and Kilimali, V. A. E .B. (1990) Antimalarial activity of Tanzanian medicinal plants. Planta Med., 56, 368-370.

Weisburger, E. K. (1977) Carcinogenity studies on halogenated hydrocarbons. Environ. Health Perspect., 21,7-16.

Westbrook-Collins, B., Allen, J. W., Shariff, Y. and Campbell, J. (1990) Further evidence that dichlormethane did not induce chromosome damage. J. Appl. Toxicol. 10, $79-81$

World Health Organization (WHO) (2008) "Traditional medicine" Fact sheet number: 134 (December).

Wyrobek, A.J. and Bruce, W.R. (1978) The induction of sperm-shape abnormalities in mice and humans. In: Hollaender A., de Serres F.J., editors. vol. 5. Plenum Press, New York. pp. 257-285. (Principles and Methods for their Detection).

Yosida, T.H. and Amano, K. (1965) Autosomal polymprphism in laboratory bred and wild Norway rats, Rattus norvegicus. Misima chromosoma 16, 658-667.

Young, D.S., Pestaner, L.C. and Gibberman, V. (1975) Effect of drugs on clinical laboratory tests. Clinical Chemistry, 21, 1D-432D.

Young, D.S., Thomas, D.W., Friedman, R.B. and Pestaner, L.C. (1972) Effects of drugs on clinical laboratory tests. Clinical Chemistry, 18 (1), 1041-1303.

Zubair, M., Nybom, H., Ahnlund, M. and Rumpunen, K. (2012) Detection of genetic and phytochemical differences between and within populations of Plantago major L. (plantain). Scientia Horticulturae, 136, 9-16.

(Received 1/11/2016; accepted 24/11/2016) 


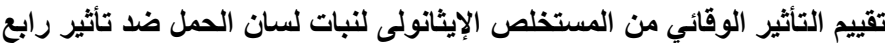

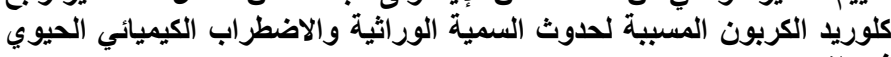

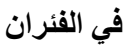

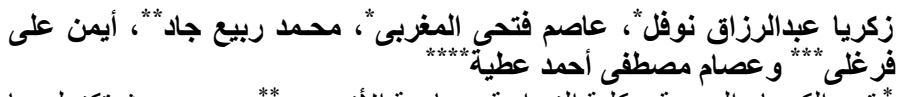

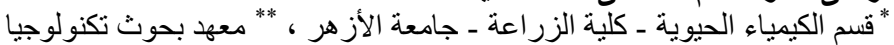

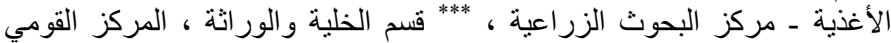

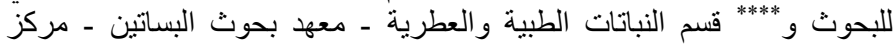
البحوث الزر اعية ـ القاهرة ـ مصر.

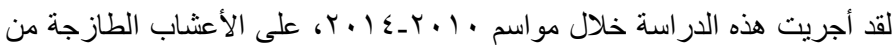

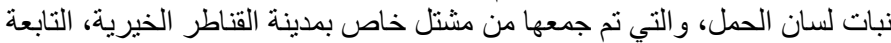

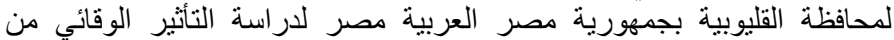

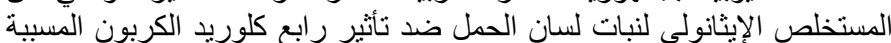
للتوتر الناجم عن الأكسدة في الأنسجة المختلفة في الفئران.

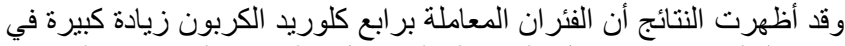

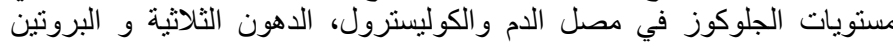

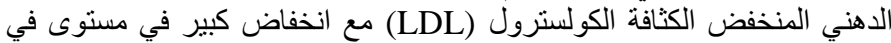

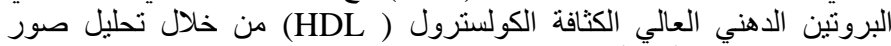

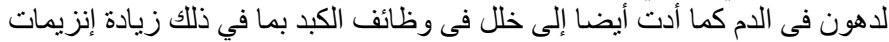

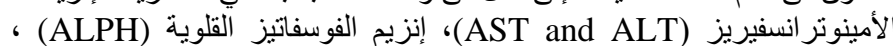

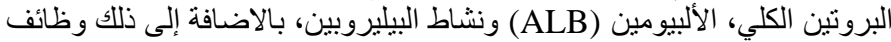

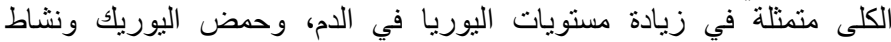

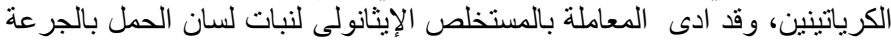

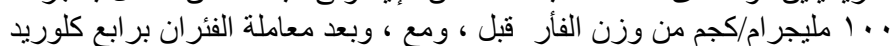

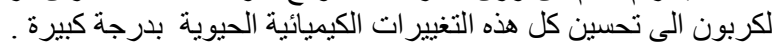

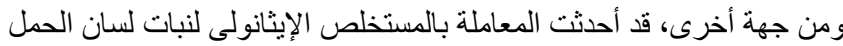

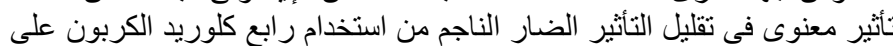

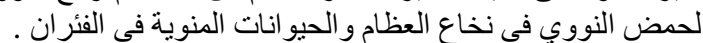

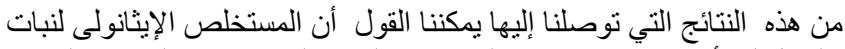

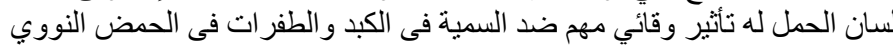

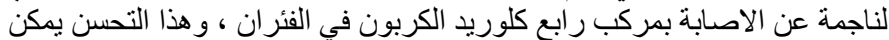
ارجاعه الى خصائص النبات المضادية ليع للأكسدة.

الكلمات الدالة: لسان الحمل، رابع كلوريد الكربون، سمية أنسجة الكبد، شذوذ

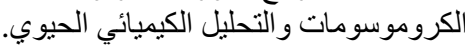

